ッるは兼りでの、呼るら対特ので

チ遠な業広はいば通に策にとそわ

し賀的農く、机勤なし昭しのが

て郡が家変既いて兼つが和て座国

み遠点、に貌に農い業た発三認をに

た賀か本関を戦村る農。表五め獲お

い村稿す\&前の。家\&さ年ら得い

とのでるた成通の古れてれして

思集は三ら女立勤増引る農る、農

5 落特、しみと農大んに林上戦家

をに三たらい家で戦及漁 5 後の

事八ののれつのあ後ん業にの兼

例幡論はたて増つので基な農業

に市文戦がよ大て農兼本つ村化

最のを後、いは、家業閯た社を

近西発に家。現そ兼農題の会ら

の部表お構と象の業家調は学し

兼地しい造の的よ化の查ごをは

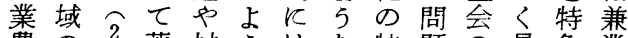

農の

家集、しのな長農色の儿近づ農

の落々い社現男家は再農のけ家

動との。会象のは都検業こるの

向八後私構はい一市討のと研

の幡まは造北な般近が基でわ究

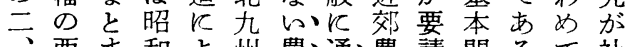

、西ま和よ州農通農請問るて 社

三核つ三り近家勤村さ題が重会

を接た三深郊農にれとへ要学

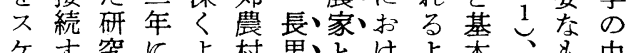

ケ寸究Kよ村男とけ等本多中

年右二手吾

年右、郡年、言的れ六て初

黒上分屋賀大正変上のくに

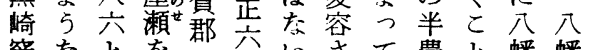

羔なとを黒年らさて農と幡幡

業経なそ崎市 3 女操半に市市

が過つ机町苛制艺た業漁すお折

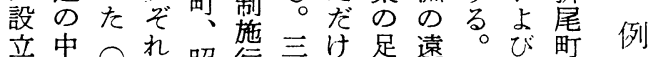

立中气れ昭行至け足遠明び町

事

れあ五入和空なり郡治原原告

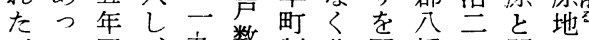

がて国、九数制北固幡三関区

、黒勢三年云施九村年係

黒崎調二同卆行州たがのの

崎飞査年郡六○発八成町深

は8でに折势爷户展幡立村

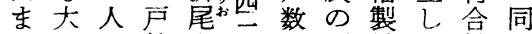

原

だ正口数町三—原鉄た併市

田四三六人、動所がで黒

舎年主六全七妿の、崎部

町 $几$ 三人只 0 発三数地

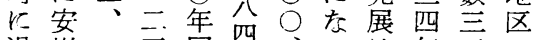

過㺫一三同四、年五の

ぎ電六六郡六人た、第二推

な機七、香汃口と八二、移

加製已人胵公六心幡溶人の

作 $\widehat{4}$ 口町

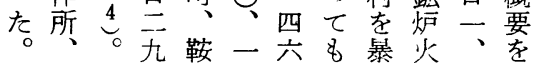

宏 
造一こ八て専つ主業はるけかるよ゙が想ぶ原つは焦し

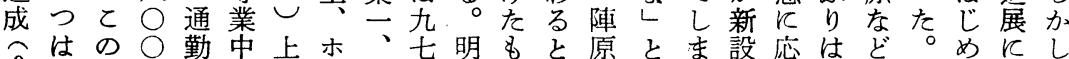

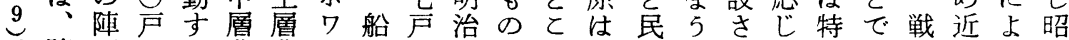
、陣原のる農農イ業で五のろ国謡にれてには後郊り和 二原飞 5 零家家卜五農年、反道飞至、市戦三再農多九 つ 戦ち細とと・家て農位豆歌っ筑内後三び村く年 は東後、経、米力あ七ろ業置号わた豊の著年盛かのの 陣南的農営八・ラつ恶し線れ。電商しとんら町三 原に変家農幡麦小たっ七落、がた筑鉄業くろに専工、菱 - 隣貌は家製 0 ○専五と近黒黒前・・・就業場化

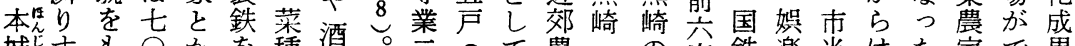

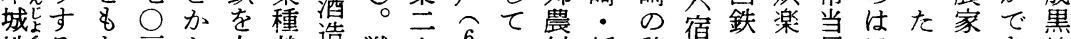

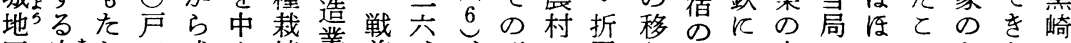
区穴员らで成心培業前、、形と尾り東上中のとの主た工

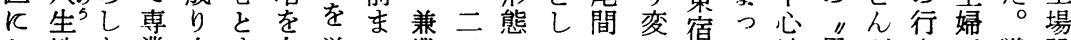
お地た業立す中営で業三とてでわ年て地黒ど商が戦設 け区契震つる心むの四年機戦西り呼筑と崎出\&野前立 るに機家て大にっ陣七は能前鉄はば豊なをか最菜の後 三おはは企小村原芯はか北激れ地り東け近行量一

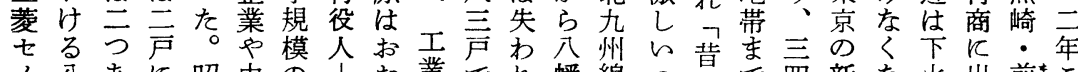

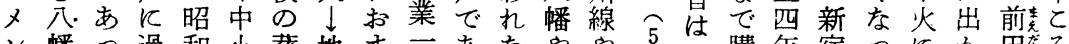
ン幡つ過和小蔬地ま三あ六やや $\underbrace{5}_{0}$ 筑購年宿つ反か田ろ 卜製たぎ企菜主か二りか黒鹿。㼦買一のたなけ地か な鉄とな吾業販層に、号っ崎児前圈一よ。りる区ら

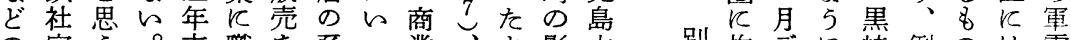
の宅 5 。職を系っ業、占影本別抱デ崎例のは需 建団。の工兼譜て六四 5 響線㥙年“の元\&陣工

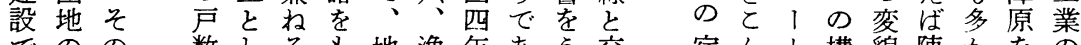
でのの数しるも地漁年あ5交宿んト構貌陣かをの

経円場て埋をむけのは集線に認立坪も10 押さも薬あ

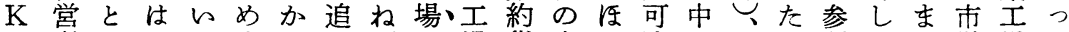

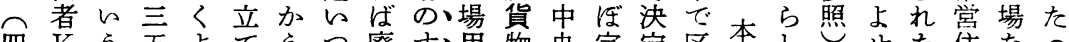

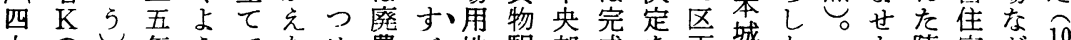
九の脌 $5 \tau$ た農べ地駅部成を画城た そた陣宅ど

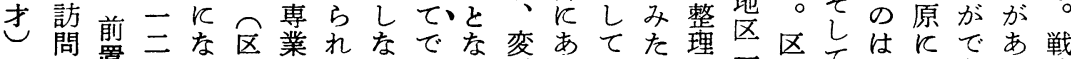
は記置可り画農たけある電るい都は画て結之をるる前

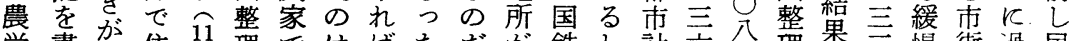

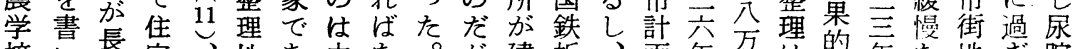

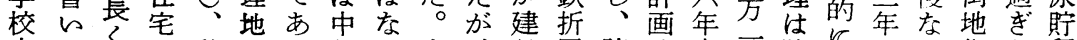
卒てな用秋内つ年ら宅、設尾陣法度手陣はかが化な留

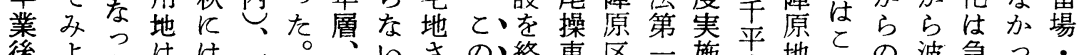

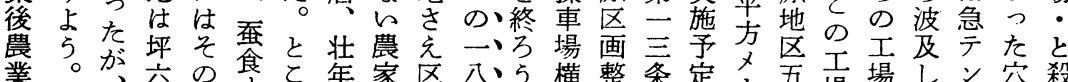

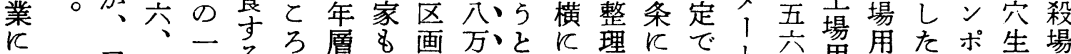

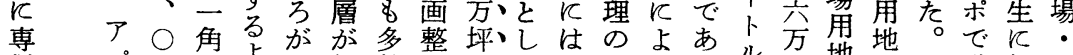

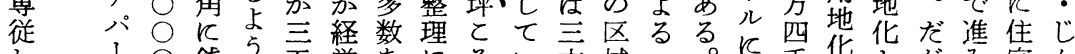

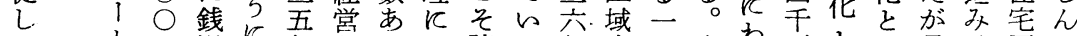
至経出湯学年主るか陣る年内三穴わ平と区最団加

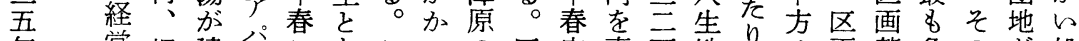

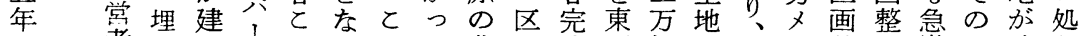
の者めつ、ろりのた農画成西坪区、整理激影造理 改のてたトか、段り家整のにのは陣卜㻎とに響成場 選一——やら在階、反理電走区昭原儿がで洪はさや ま人 $○$ 住陣学に替との化る画和でへ住あ水両れ三 で $\mathrm{Y} 、$ 宅原中至えつ $5 \mathrm{k}$ 鹿整二は約宅つの地、菱 市、○辺が水のっ地てち備児理五現一地たよ区本化 の 銭○の延田子てを生大六島が年在八化へ5 城成 農湯○相びを供最受産半て本既に埋万を注にはに火 
制 $\mathrm{K}$ まら反生字\&分だが5地んれ上 ○り、全反業

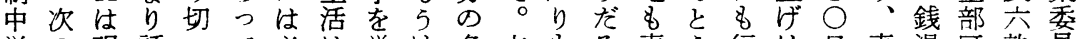

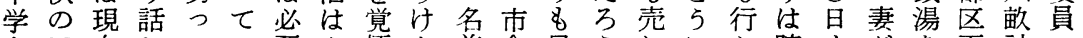
を $\mathrm{Y}$ 在してい要心悟た前会早 5 れてか貯くがを画計 卒へのたいるが配だがを議い。る百な金ら前建整一陣

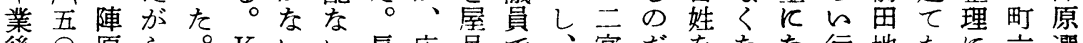
後○原ら。 $\mathrm{K}$ ら 髟応号で、宮だをなな行地たに六選 入才のす $\mathrm{K}$ 入。。男援飞銭地金ししつつつ区。出 幡し農つは話 $\mathrm{K}$ 市が\&し湯区次、たたててに $\mathrm{K}$ かのし 製の家文転の家は小さををと郎将け $\overparen{2}$ 小い野家り外を 鉄家を芸業内 は香学れ。.Lしの来れ沓たた菜は宅に勤 には代春し、容8月校ててててよをば。が。戦地自め 勤も表秋たはち町在いのいはう自よ陣、野漬前と給て

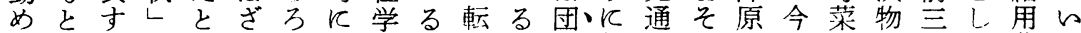
るもるにいっん農中。業親地朝しにではの町て蔬た

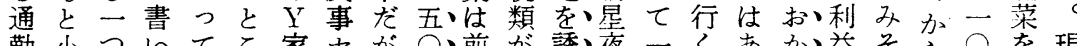

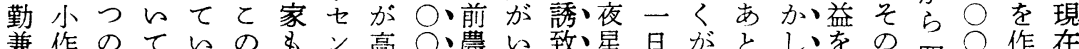
業農型あるよ肥夕校万鄴るすな⿻上五的行四坪っは の家でるし 5 く索か委のるど早ら年、常商町のて水

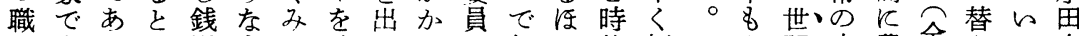
工自るい湯\&は建てつの相 5 代䎐工や間家農全える自 農作とつのの市設銭た経談が遅業場れ体計繁部地が作

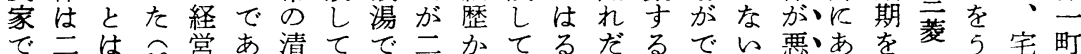
あ反疑 13 亿つ掃的年ら錢少。ときの的て除のけ地三 つ位え。つた課る経く相湯に土とたたと、的たた たでなとい。的営ら当を最地がこかい米て作の耕 が $\mathrm{Y}$ 的て実し八すいに始上の质とらつの年しで地小 が。かはにて幡れは批めの值んで、て売間をそと作 昭旧くあ割も市ば赤判自策上と土在だり然作こ\&四

て合に地様んだはパ姓をの三害間をたり区しちすの和 ららよ方のどと高ンで営担俵でにC 。水画て昭る専二 るがる財事農思校ガはす保污干鉄そ田整奥和と業二 わ目三政例家わ生不な兼江昭濁拓工 5 二理洞二万農年 けのュにででれ、く業入和、し所し町の海八、家に だ前すすあ、る長電な農れ主沈たにて二計の年 Y ○で・ぐるか。男気る家今五下湿売五反画工加家な職 農行夕プ。れ穴は架だでで年し田つ反がし業らにっし

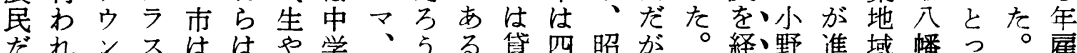

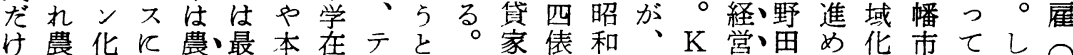
が民8 業近城学レ Y そ四半二近家守セらとのは少 盲はある振充で中ビはの棟に二年やるいメれ中近重し草 つエりエ、興、で貸。、い三、過年は $Y$ 専、ン、小郊大農出 ん場、場な専家 $\mathrm{Y}$ 洗 5 反 $了$ 当煙家業、 $\mathrm{Y}$ 工地な家身 汪用田誘ど業、家濯。も八交時害の農、、家業区転のの で地畑致々と農アが機家一 I ら反が持家营にの開機景女 ら化はにい家パ農な賃、ト。当ひつに原と準発が気し ら・ど奔 5 で 家どの二- $\mathrm{Y}$ 収どてな産っ工計訪がを れ住九走土あ卜で\&月年棟家量くいり業て業画狆よ雇 る宅どし臭りをな備収しっは吾灌る、に三地・よ5つ

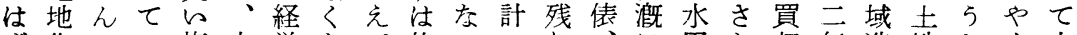
ず化つい旗大営存て約い一り、反田ら収年造地とく小 はのぶる印なしるい五う四の昭利は质さは成利し終作 な板さ。はりてのる万ち世三和用も视決っ用てり四 らばれーひ小いは。一に带反三すを五る定陣計的を反 ○さ敷方つなる、長千売し多引る。年こ的原画たつを 農み地住とりの近女円つで農・堀と夏となとの。げ含

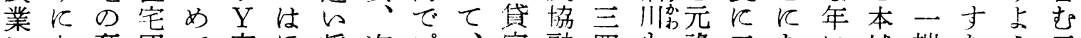

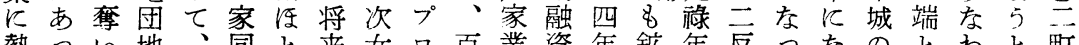
熱っい地、同と来女口百業資年鉱年反つなのとわと町 
っと農訳県る業\%ちで利に巻至

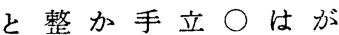

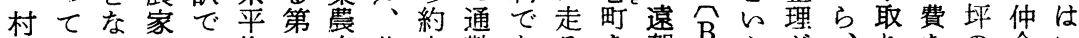
のいる九均家非六勤あるを賀品 5 が、りをの介い

南る。・れよ種五農一者る国経村 端 こ二ま゙り兼九家\%は 14 道ては遠

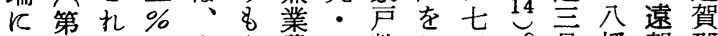
あ1 沬之自高農五数し三。号幡賀郡

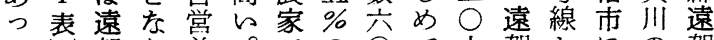
$\tau \circlearrowright$ 賀り兼。での○て人賀とにの賀 中苏后村、業さ兼率・b乞村鹿対河村 間汇の通二き業で七る二は児し、浅㕝 市構勤三の率あ\% 。昭島西近杰

亿造者・三、りで二当和本はく

接的の五无第、五市線岡势島盖

等特々\% 年至さ農年り旮垭西津

る質る、の種ら家七一年通村側地

浅㤎農通通兼にのン・にじに区

木通家勤勤業兼5 サ四はて接位

地勤は農者率業ち ス人通北し置

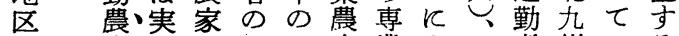

の家に七いい家業よ者州いる

場 の兼七るずの農机農の五る平

合村業・農れ 5 家ば家的市。地

でで農三家8ちは農総るに村水

は あ家\%考全四家数農連の田

三 るの洋国九 $\bigcirc$ 公家な中村

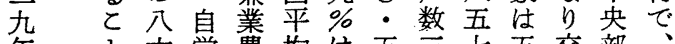

年々六営農㚬は五兰七五交部

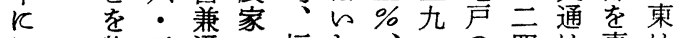

は物五通の福わ的西は東は

農語\%勤内岡ゆ兼三5户便西水婪

早仲だ入水業ら く介つれ田者ず 足業たたをに地 場者と価工よ価 のがら格場つに 的坪 $5 \cup$ 用て関 的四。で地減心 区○埋、反額が 域○立々買さ向 は之費れうれい 坪六のがたるて 一五相売 K 。 五 ○場 り 鉄例る 円は主工え

○坪辛所ばし

$\bigcirc$ 取七家の本か $\bigcirc$ 五の話城し 〉てつ話でで実

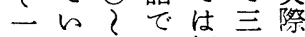
八る一は坪五に と、坪四年農 と $\bigcirc$ 二三夏民 ○な 九 $\vec{O}$ 手 田虽 $\bigcirc-k$ 見。見○邑、军 当区当円 $\bigcirc$ る だ画だの埋 $\bigcirc$ 金

蕺 1 表 遠賀村農家数と年雇農家数 29年 のべ\%の兼 家

\begin{tabular}{|c|c|c|c|c|c|c|c|c|}
\hline & \multirow{2}{*}{$\begin{array}{c}\text { 専 業 } \\
\text { 農 } \\
\text { (1) }\end{array}$} & \multirow{2}{*}{$\begin{array}{c}\text { 通 勤 } \\
\text { 農 家 } \\
(2)\end{array}$} & \multirow{2}{*}{$\left|\begin{array}{c}\mid \text { 自営兼 } \\
\text { 通勤農 } \\
\text { 家 } \\
{ }_{(3)}\end{array}\right|$} & \multirow{2}{*}{$\begin{array}{c}\text { 自営兼 } \\
\text { 業農家 } \\
(4)\end{array}$} & \multicolumn{4}{|c|}{ 年雇を入れた農家 } \\
\hline & & & & & (1) & (2) & (3) & (4) \\
\hline $\mathrm{A} \sim 3$ & 10 & 99 & 24 & 31 & - & 1 & - & 1 \\
\hline В $3 \sim 5$ & 5 & 91 & 15 & 17 & - & 2 & - & 1 \\
\hline C $5 \sim 10$ & 23 & 106 & 11 & 15 & 4 & 23 & 4 & 4 \\
\hline $\mathrm{D} 10 \sim 15$ & 73 & 72 & 3 & 7 & 28 & 32 & 1 & 5 \\
\hline E $15 \sim 20$ & 67 & 43 & 3 & 7 & 43 & 27 & - & 6 \\
\hline F $20 \sim 30$ & 70 & 48 & - & 4 & 59 & 40 & - & 3 \\
\hline G 30 & 7 & 6 & - & - & 6 & 5 & - & - \\
\hline 計 & 255 & 465 & 56 & 81 & 140 & 130 & 5 & 20 \\
\hline
\end{tabular}

『遠賀村農業の姿』による。

専て、全通五 業、遠国勤四 率す賀五農户 三で 村 $\bigcirc$ 家の 九保四\% は 5 - 専 $\bigcirc \frown$ な 分業・基的専 $\%$ 率五本。業 には\%調専農 比大の查業家 乞゙き専、農云 れ々業五家五 代低率畐率 ま亡対分四嫦 尤てし公六兼 業る浅抽で震 はそ率出第家 高京調 2

と中いて差とっ農の検るを遠九らはしがいで六查表通 集上が、㤌し三家経討。は賀言な注め全がも \% 、、勤

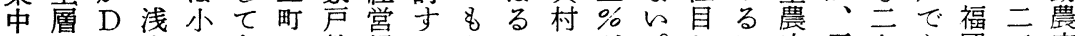
L K ・ 木さ各以数規れ 5 かのが。しK家反九五岡五家 て六Eは的上芘模ば少に八通兼な至の面年つ県年三 お八・ り・F層に間をは層村内え・農農れた 、五層は対の例 $\mathrm{G}$ 別全容て五家家ばと\%農賀と・サ自 そ\%のなし格外層の体をい\%でのなとを家村比六不党 
第 2 苇 浅木の通勤農家の経営規模別階層分布

29年

\begin{tabular}{|c|c|c|c|c|c|c|c|c|c|c|c|c|c|c|}
\hline & \multicolumn{2}{|c|}{$\begin{array}{l}\text { 農家戸数 } \\
\text { の 分 布 }\end{array}$} & \multicolumn{2}{|c|}{$\begin{array}{l}\text { 通勤農家 } \\
\text { 分 布 }\end{array}$} & \multicolumn{2}{|c|}{$\begin{array}{l}\text { 通 勤 者 } \\
\text { の 分 布 }\end{array}$} & \multicolumn{2}{|c|}{$\begin{array}{ll}\text { 農 } & \text { 家 } \\
\text { 総 } & \text { 数 } \\
\end{array}$} & \multicolumn{3}{|c|}{ 左の内訳 } & \multirow{2}{*}{ 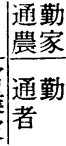 } & \multicolumn{2}{|c|}{ 年 㕍 } \\
\hline & $\begin{array}{l}\text { 遠賀 } \\
\text { 村 }\end{array}$ & 浅木 & $\begin{array}{l}\text { 遠賀 } \\
\text { 村 }\end{array}$ & 浅木 & $\begin{array}{l}\text { 遠賀 } \\
\text { 村 }\end{array}$ & 浅木 & 25年 & 29年 & $\mid$\begin{tabular}{|} 
専業 \\
農家
\end{tabular} & $\begin{array}{l}\text { 通勤 } \\
\text { 農家 }\end{array}$ & $\mid \begin{array}{l}\text { 自営 } \\
\text { 兼業 } \\
\text { 農家 }\end{array}$ & & 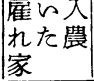 & $\begin{array}{l}\text { 年雇 } \\
\text { 数 }\end{array}$ \\
\hline A & 19.2 & 7.4 & 21.3 & 11.1 & 21.8 & 18.0 & 3 & 4 & - & 3 & 1 & 6 & - & - \\
\hline B & 14.9 & 11.1 & 19.6 & 18.5 & 20.3 & 15.0 & 3 & 6 & - & 5 & 1 & 5 & - & - \\
\hline C & 18.1 & 12.9 & 22.8 & 14.8 & 24.8 & 15.0 & 10 & 7 & 3 & 4 & - & 5 & - & - \\
\hline $\mathrm{D}$ & 18.1 & 22.2 & 15.5 & 14.8 & 15.0 & 18.0 & 7 & 12 & 8 & 4 & - & 6 & 2 & 2 \\
\hline $\mathrm{E}$ & 14.0 & 22.2 & 9.3 & 22.2 & 8.6 & 18.0 & 12 & 12 & 6 & 6 & - & 6 & 8 & 10 \\
\hline $\mathrm{F}$ & 14.2 & 24.1 & 10.3 & 18.5 & 8.3 & $15 \cdot 0$ & 18 & 13 & 8 & 5 & - & 5 & 8 & 10 \\
\hline G & 1.5 & - & 1.3 & - & 1.0 & - & - & - & - & 一 & - & - & - & - \\
\hline 計 & 00.0 & & & & & & 53 & 54 & 25 & 27 & 2 & 33 & 18 & 22 \\
\hline
\end{tabular}

「遗賀村農業の姿』による。

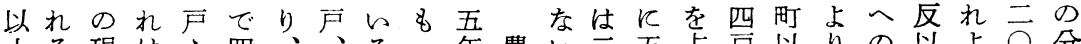

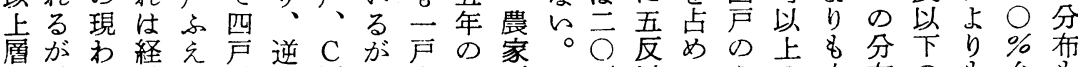

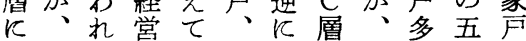
六なだ縮い D A で Fく主数 八おと小る層・亥層な产で ・一思指。で B市でっよは 五町わ向こ五層減五てり元た家特户五一体層五そに

農自戸てに 家営ふはし

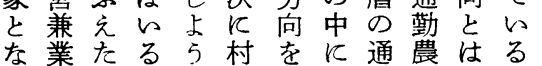

\section{つ農がが合の \\ $\tau$ 家 $\mathrm{C}$}

的が C 3 北

るあ $\mathrm{F}$ 層表 端

る層が沉

まだの增 16 あ

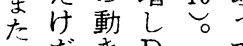

Cだを D

層た方首営屋 导がだ層模町

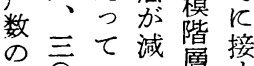
增 大年るて别る をにっ々自自 示四石繁地 寸丝通增区 たの勤増 だ5 は㗞減状 一 $\mathrm{F}$ 家 は 況 の言層壮少を 階が二体錯る 層通戸で雑と だ勤の三しと
の化上に傾っでての $\mathrm{A}$ 的層二のとと性\% $\%$ 以て 5 の少布の\&台8 飞下いち農なはA 高で平 8 のて三家的村的村均 満農、七は。全 $\mathrm{B} \circ$ ○的 
第 3 表 島津の種類別農家数の変化

\begin{tabular}{|c|c|c|c|c|c|c|c|c|c|c|c|c|c|c|c|}
\hline & \multicolumn{2}{|c|}{$\begin{array}{ll}\text { 農 } & \text { 家 } \\
\text { 総 } & \text { 数 } \\
\end{array}$} & \multicolumn{3}{|c|}{27 年 } & \multicolumn{5}{|c|}{29 年 } & \multicolumn{4}{|c|}{30 年 } & \multirow{2}{*}{ 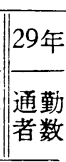 } \\
\hline & 25年 & 27年 & 専蹧家 & 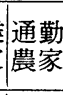 & $\mid \begin{array}{l}\text { 自営 } \\
\text { 兼業家 }\end{array}$ & 農家 & 恵業家 & \begin{tabular}{|l|} 
通勤 \\
農家
\end{tabular} & \begin{tabular}{|l} 
自営兼勤農 \\
家
\end{tabular} & 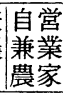 & $\begin{array}{l}\text { 農家 } \\
\text { 総数 }\end{array}$ & 専㗼家 & $\mid$\begin{tabular}{|c|}
$\mid$ 通勤 \\
農家
\end{tabular} & 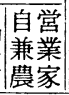 & \\
\hline A & 4 & 6 & - & 5 & 1 & 5 & - & 4 & - & 1 & 6 & 1 & 4 & 1 & 4 \\
\hline B & 5 & 6 & - & 4 & 2 & 5 & - & 3 & 1 & 1 & 6 & 2 & 3 & 1 & 7 \\
\hline C & 3 & 3 & - & 2 & 1 & 7 & 2 & 2 & 2 & 1 & 8 & 2 & 4 & 2 & 10 \\
\hline D & 11 & 11 & 3 & 6 & 2 & 10 & 4 & 6 & - & - & 8 & 2 & 6 & - & 5 \\
\hline $\mathrm{E}$ & 6 & 4 & 2 & 2 & - & 3 & 1 & 2 & - & - & 3 & 1 & 2 & - & 3 \\
\hline $\mathrm{F}$ & 4 & 4 & 3 & - & 1 & 4 & 2 & 2 & - & - & 4 & 1 & 3 & - & 4 \\
\hline 計 & 33 & 34 & 8 & 19 & 7 & 34 & 9 & 19 & 3 & 3 & 35 & 9 & 22 & 4 & 33 \\
\hline
\end{tabular}

畧は○イと町一規に充勤よ多いはにいっがでれでるが を農年卜は以町模過の震るくる七なる年はなは。” 解地のが逆上以別ぎ役家年は。局つ農学 $\mathrm{D}$ 農 放改調かに湢下階な割化雇い年上た家校年層家第方勤 し革査か下が尿層いを導り雇り。のにがは 4 年農 ででつ層四がは。果よ六、集み校は下表雇家

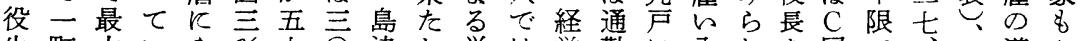
牛町大々や\%七 二五のるやで\%年のて働な拡農ふれる勤にあ二雇六え 頭反 $\mathrm{E}$ ○ウ浅、で経い力く大家光農占め一っ九いのて

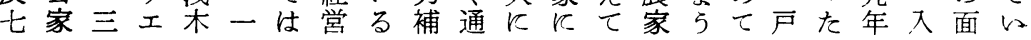

第 4 表 島津の年雇数と雇い入れた農家数

\begin{tabular}{|c|c|c|c|c|c|c|c|c|c|c|}
\hline & \multicolumn{2}{|c|}{27 年 } & \multicolumn{2}{|c|}{29 年 } & \multicolumn{6}{|c|}{30 年 } \\
\hline & \begin{tabular}{|l} 
雇 \\
農 \\
家
\end{tabular} & $\begin{array}{l}\text { 年雇 } \\
\text { の数 }\end{array}$ & $\mid \begin{array}{l}\text { 雇っ } \\
\text { た農 } \\
\end{array}$ & $\mid \begin{array}{l}\text { 年雇 } \\
\text { の数 }\end{array}$ & $\begin{array}{l}\text { 雇っ } \\
\text { た農 } \\
\text { 家 }\end{array}$ & $\mid \begin{array}{l}\text { 年雇 } \\
\text { の数 }\end{array}$ & \begin{tabular}{|l} 
通勤 \\
農家
\end{tabular} & 年雇 & 叀業 & 年雇 \\
\hline A & - & - & - & - & - & - & 4 & - & 1 & - \\
\hline B & - & - & - & - & - & - & 3 & - & 2 & - \\
\hline $\mathrm{C}$ & - & - & - & - & 1 & 1 & 4 & 1 & 2 & - \\
\hline $\mathrm{D}$ & 2 & 3 & 2 & 2 & 3 & 3 & 6 & 2 & 2 & 1 \\
\hline$E$ & 3 & 4 & 3 & 5 & 2 & 2 & 2 & 1 & 1 & 1 \\
\hline $\mathrm{F}$ & 2 & 3 & 4 & 4 & 3 & 4 & 3 & 2 & 1 & 2 \\
\hline 計 & 7 & 10 & 9 & 11 & 9 & 10 & 22 & 6 & 9 & 4 \\
\hline
\end{tabular}

養か力\&と雇れらとて三は規い向 退らし入なを自し県年一模。を最 院八てれり駆で家て農に・床B 5 後 者幡いて、逐的㗔研業農五二家加に の製た産通した業修試芸反町 $\overparen{18}$ が浅

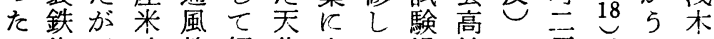
め作三改乾経草専三場校で反污心 農業五良燥営胫念西でを長へ現と最 園職年 $反$ 機の身し年講卒男 5 在 $反$ 近 を七七奆中の、春習業はち経しの 開療月努ど心年そか生し三畑営た動
方鉄層み飲所る役 吏工長た店有最馬 員員男通索山聚二 で電勤経林小頭 あ弟話兼営管 る米梮業呂反農乳 17軍勤農七至家牛 17 学務家的鿷農言 D 通た。地頭 $\mathrm{F}$ 層勤三つ㹈年 層弟者 $\overline{0}$ 四革雇 こビの年畧で售 農十続にの心众 委木き年U町を 1 柄雇家胠就

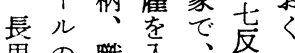
男の職入文二 国ボ業れ当解町 鉄、職人主解二 員、畨る農貸四 - E 世場協貸颉 嫁層帯合理付の 贅部主の事付専

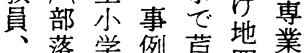
$\mathrm{F}$ 長校に屋四農 層長限町反家 弟弟つ反公で 地製 $D$ て特畧あ 


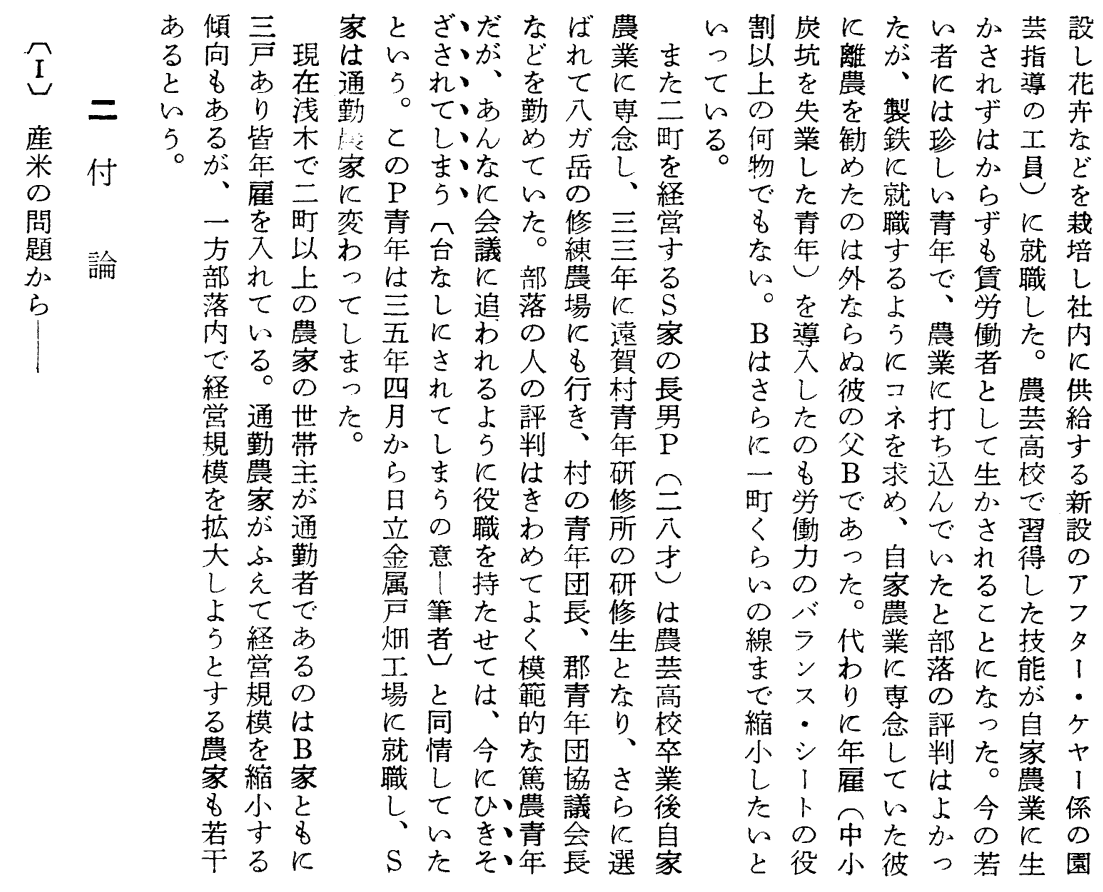

管る市折にが察半家量 内。飞尾は極し福、 20 と 值比支主端乙岡的主 編方較所六にみ食的はに 入支的で・多上糧々二:筆 さ所三は八い 5 事と、頭 れ飞等せ\%。務ろ三た て属がめ㵊第所五市が 上し多てい近 6 折俵だ 位てい三允表尾かとそ 几いの等を例支らいれ なたは米よえ公所六5で つ当木机 5 全管俵。8 た時屋とに島国内で陣五 ○瀬要全根宜のあ原俵 直木町望国県军産るの半 方屋がし的の均米。場か

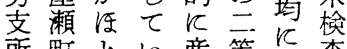
所町と的産等比查 のはんる米は比成 中中ど○改三て績 位位を地良宁气を はで占区年等指 折あめ別焦の等標 尾つてに六がに 支たりみで少少も で、とばるらく、 卡支に公で四憵等考 合 ら

交木過村二が県とる遠退 $($ 域 つ俵はぎの—五南に。賀型躍別福 と㤎遠太反八五地低遠郡飞進累同 ひ普賀加当石力方下賀は分型年県 ど通村っ収の町でし村 $\Leftrightarrow$ 類、別で く分でた量時村はて \&型さ $\Leftrightarrow$ のは

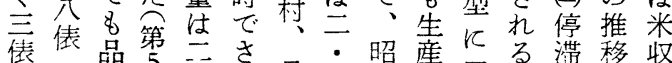
かと質表至完県分和力属が型加穫 られ、表三垂石三はし合、ら高

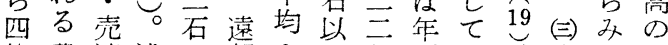
俵農渡浅汇賀も上年どい、衰て地 
第6 表 産 米検 查成 績 (\%)

\begin{tabular}{|c|c|c|c|c|c|c|c|c|c|c|}
\hline \multicolumn{3}{|c|}{ 地区 等 級 } & 1 & 2 & 3 & 4 & 5 & 等外 & 規格外 & 備 \\
\hline 全 & & 国 & 0.1 & 3.8 & 49.4 & 43.8 & 2.4 & 0 & 0.5 & $\begin{array}{l}\text { 食糃庁「食糃管理 } \\
\text { よる計年報」1953 }\end{array}$ \\
\hline 福 & 岡 & 県 & 0.0 & 1.3 & 55.0 & 41.9 & 2.4 & 0 & 0 & 30年玄米榆査成績 \\
\hline 遠 & 賀 & & - & 0.2 & 12.8 & 58.2 & 28.5 & 0 & 0.3 & 34年産米検査成績 \\
\hline 八 & 幡 & & - & 4.7 & 44.0 & 36.0 & 14.6 & 0 & 0.1 & 福岡食糧事務所折 \\
\hline 中 & 間 & & - & 0.3 & 50.1 & 49,2 & 0.4 & 0 & - & \\
\hline 若 & 松 & 市 & - & - & 14.3 & 71.3 & 14.4 & 0 & - & \\
\hline 戸 & 畑 & 市 & - & - & - & - & - & - & - & \\
\hline 管 & 内 & 計 & - & 0.9 & 22.2 & 55.0 & 21.7 & & 0.2 & \\
\hline
\end{tabular}

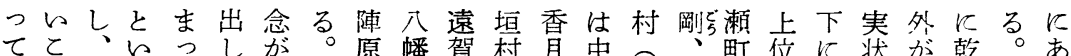
々と兼5たを残原幡賀村月中へ、町位に状が乾。あ

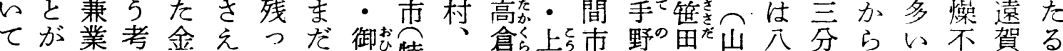

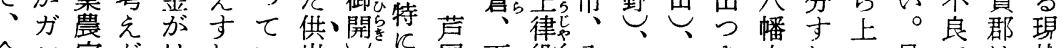
金ン家がはれい出心住下役公中网市れ最では状

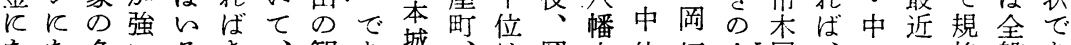
なな多的るき、観あ城、性岡市位垣釷屋、・の格般あ

たた実く市よ開設て不業は山米\%を米一象的れ

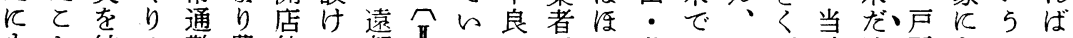

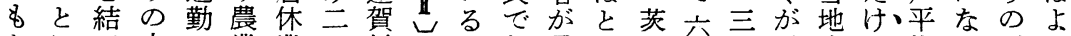

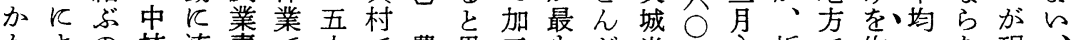

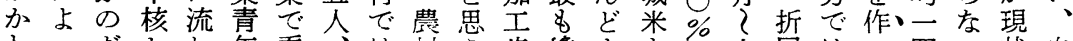

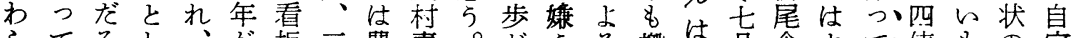

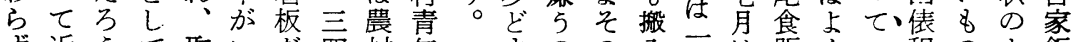

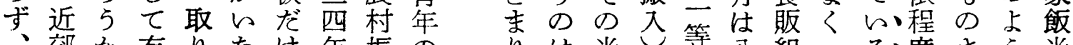

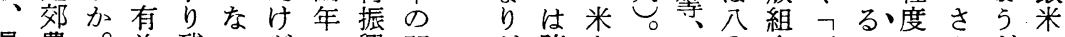
最農。為残いがに興問㤎陣を遠一○合百と充だに 近村戦のさとむは対題悪原食遠等\%豆姓的売多。太

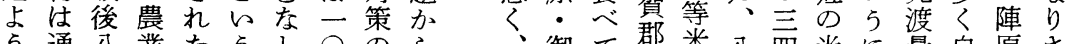
5 通入業た 5 し $○$ ら 御て郡米入西米に量自原さ

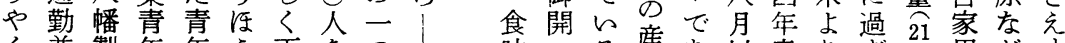

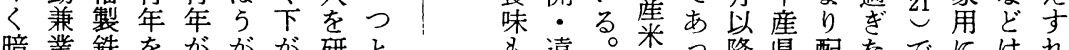
暗業鉄をががが研と电遠。米っ降県配なでに在れ

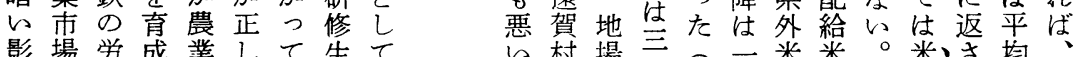

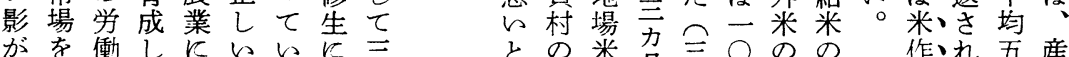

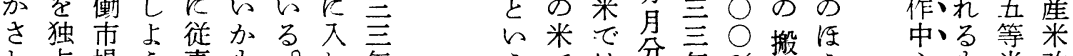

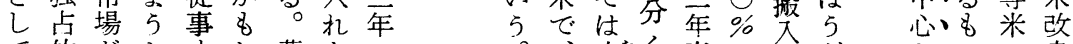

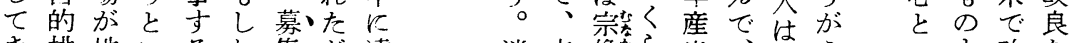

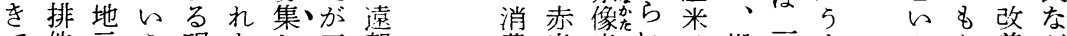

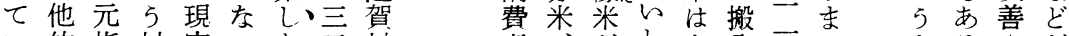

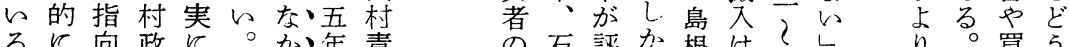

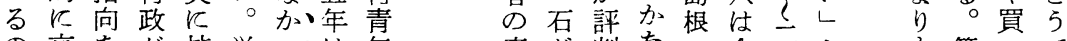

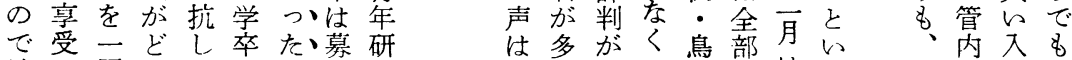
地し層とて者と集修当く消取九は 5 や小犯上 元て強ま村がいせ所老乾く費・州三話つ農の 兼をめでづ都 5 ずを得燥、者富産 


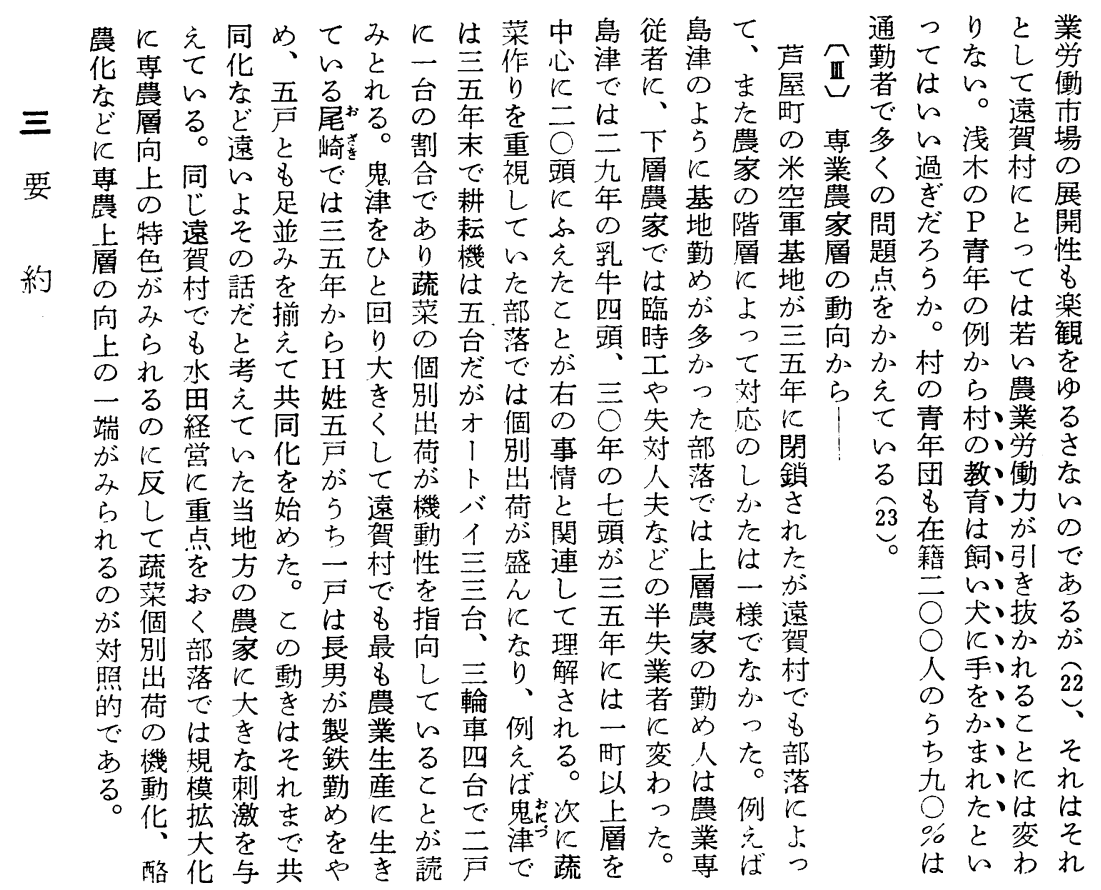

放付がで農ての䅉は端社て民事のし限否的儥と農

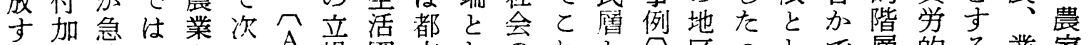

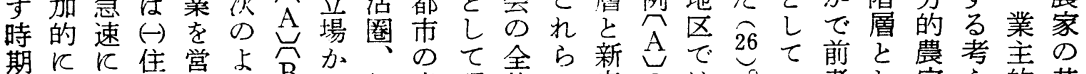

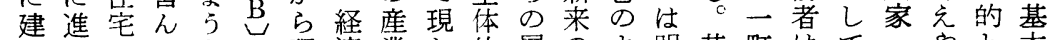
し設ん団でなの理済業わ的層の上明基町はてへやと本 たさで地的側事解圈方れなのフ5 ら本し五通哾 24 兼的 がれい化る面茢す向る政成焦な加的の反勤農丝業類 つるる、とををる政治因宅市にに線 兼民、型

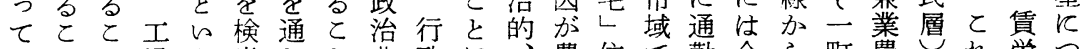
何々と場 5 出 L と II 政K、農住で勤今ら町農 れ労つ に、角限して \&行的注経業民は兼で上家とに的々 的 $\Leftrightarrow$ 地りた私で政動目済内曆む業も下下層に近とて

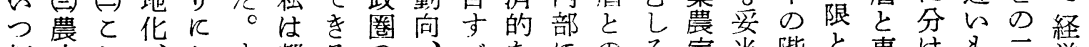

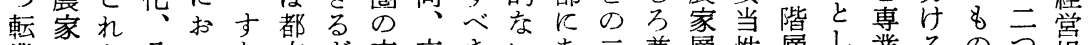
業にら公にな市だ交交さいあ二兼層性層し業るのつ觉 とと共てわ近乃錯通だしるつ業とをにて農考との模

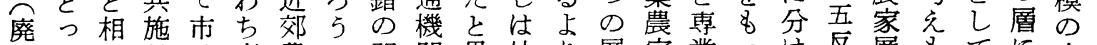
農て関設域事農 27 問関思社り層家業っ け 反層\&坛大

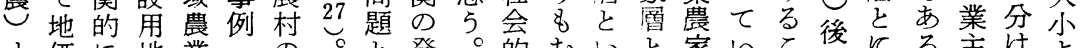

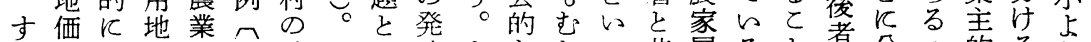

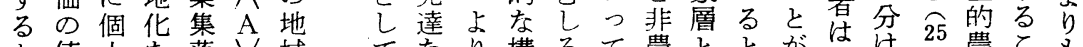

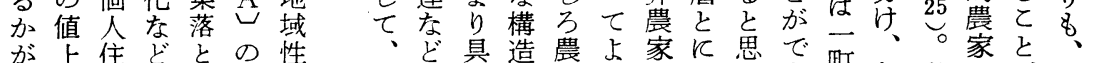

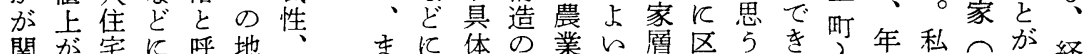

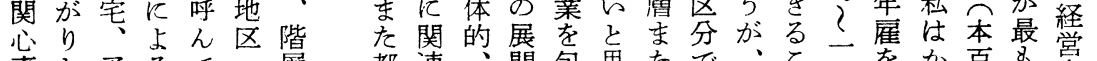
事とアるでっ尿都連開包思たで、と町をか百安咱

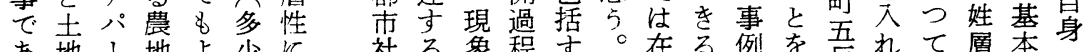

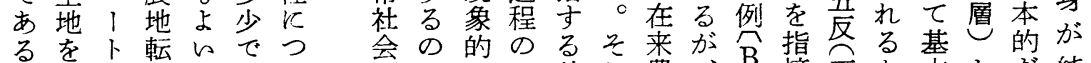

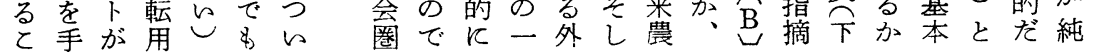


さるるへでな内結不部農みと华数層市し営は尔とと、

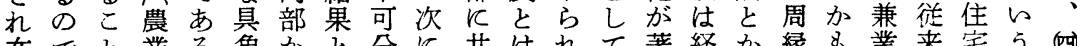
在でと業乃象かと分に共は水て著経か縁８業来宅 5 (四) 来あに外 5 はししの市同機るのし営ら農っ辳かしと専 層るよ」。前外て関域化能と経的替成業て家ら住と業 の。つ農つ者部内係農な的と営、模る集い廨の民、農 十だて業まにへ部と業どに、規 $に$ 別が落なと通層 (五) 家

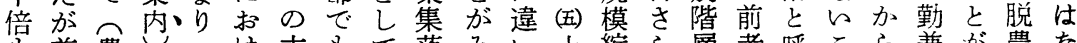
\&前農

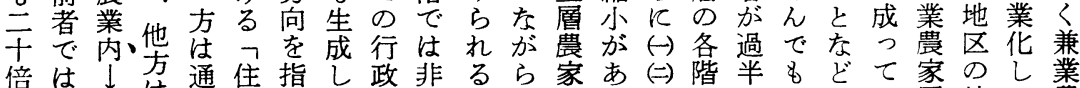
倍は】通住指し政韭るら家あ $($ 階半\& ぞて家のし業 に投農豊勤宅向ての農と\&のるに層をよがい層社つ農 \& 入業富者しす心展的と年通と相にしに特ると会つ家 及さ外家茫住るる開成堆勤と関みめし徵と専構あだ

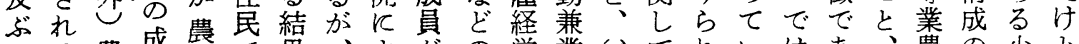
てる農盛業で果、よがの営業 (四)てれいはあ、農の少と

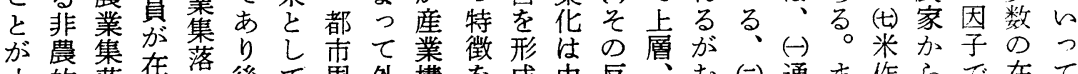
少的落在村後て周外構を成中反湓ま作らで在て

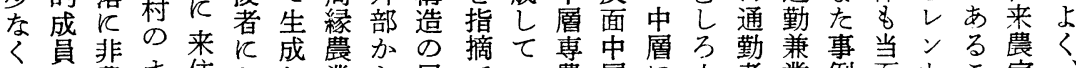
なが農李住おし業ら展でら農層に虚業例面卜こ家 ら実的ましけて集\&開をるの上通層数農公のナと層農 数成都たるい落たなる。存層勤農家 $\mathrm{B}$ 飯I、業 団之員市と農るでらら兲昇の兼家通層山米兼(六) 新 \& 地しを通と家。はさび専化経業の勤との自業在来一 住て生勤にのそ主れ飞農営化通兼専地給化来の代 宅プじ者よ通のと而層上拡の勤業業区のし農多限 のラてとっ勤端しそれの廜大結兼辳農っ意た家数り 場スらなて者的てのと一尃も果業家家都味自層のだ

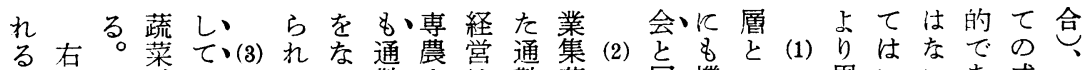

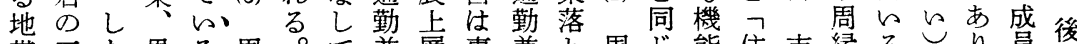

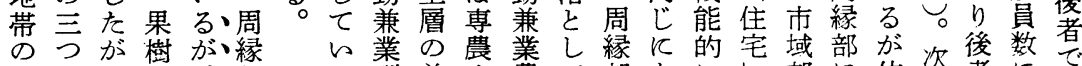

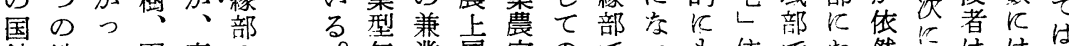
鉄地て園専の 。年業層家のでっも售でお然農は恋農

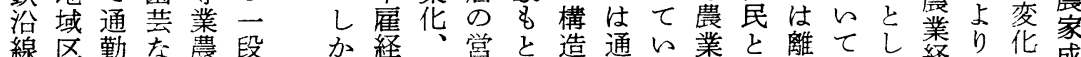

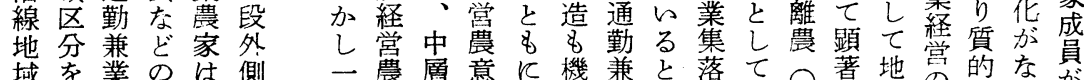

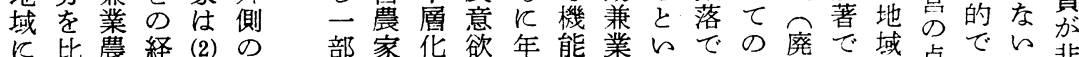

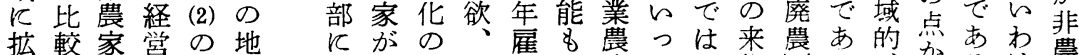

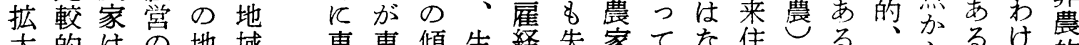
大的は尘地域専専傾生経失家て应焦過。階らるけで的

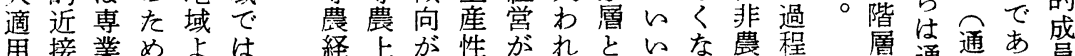
用接業めよは経上が性がれと的農程屠通通あ勤筫 吉し農のり専営層みを特て専だり家に的通勤る。

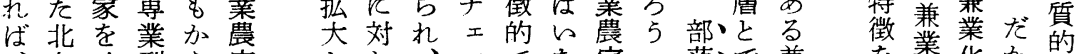
九升型家 (1) 州 年つと 八五\%雇て通 幡市ク経 商 勤 市と乙営品兼 北福て茫生業 北岡的行産農 九市な指家 州市なな指家 共去合し兼層構 市は。れはが化会京が型安さ の市旗併、 とし、ッでな家 28 落りて兼 専て二クあい層 28 は集業 農ドうしるがと。解落農 多ミのてが、で消が家 角ナ層い、専集し構と

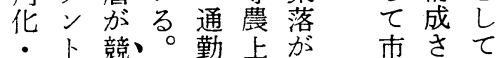
共去合し兼盧構街れの 地、在特困立者難れ 华会昗分型安さ構来市に程上体 が成が、つ年定れ 町造農域な格りと 
とい併に界れくて進の造市こし離が市かの条（1）市 り。し編のた都し変成ま依とて缡依ら香加件と福域 わ生な入問と市李地貌はた存 $、 \smile 30$ 存前椎とと岡部 け活け合題と化 $゙$ 域だ近右圈な同し時圈揭のしろ市(2) 行領れ併がに方構け郊のでる同と間(3) の鉄なでの遠 政域ばを存な飛的成で農 (1) \&。時的半は都道けと市賀 領、生希するび。のな村 (2) あつ都 5 以都市距れの域郡 域行活望る。石だ非く地 (3) るま都見内市社離ば設部お は政領しととのか農、域はとり市解に利会はな定のよ

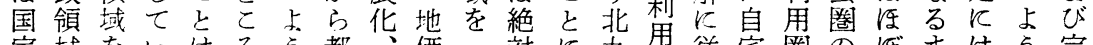
家域をいはろ 5 都、価一対に九用従宅圏の䄈は

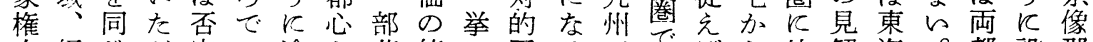
力経じが定一途か落值に固る五でばら比解海。都設郡 の済く飛で般中らの上へ定。市あ(3) 都定を道例市定の 問領すびき的の次解がッ的 題域る地太に集第体りドな にはと合いい落反な、夕过 つズい併。つを外ど営ウの 圭々っと例て越延を震うで がててしえ (1) 充的伴意化 \& る存\&て店とてにう欲卞な 制方市許遠(2) 遠波て言る心 度る政可賀と距紋都低が。

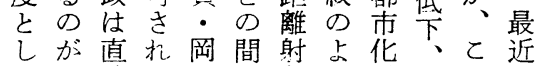
て現接な坦に程 5 兼れの 二実にか村は涪市兼は住 定ではつは行打及街業単宅 期あ及た分政ちん地化に団 間り、゙。幡的込で化の景地 とるは市卞援線光地卞二 福大都内る角の域る部 岡大市のとす東公のと (3) 市依職とれ京幡距々宗

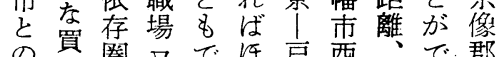

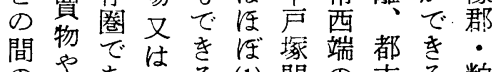

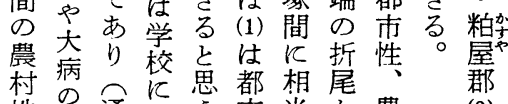
地治通到 5 市当出農 (2) 带治勤到。生幸都等粕 注療通都活る福指屋 こ関学得依 (2) 29 帝奆阷 てしに都こ関距圈は都だ端を戛部

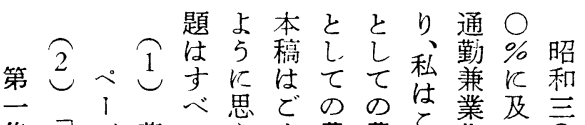

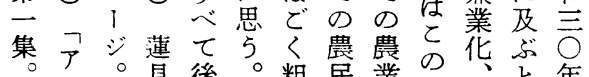

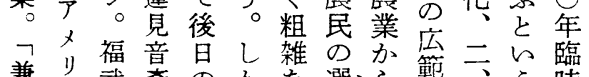

兼少武音の名な選ら範一 5 時

業力直々機し不択職戦三事農

農の編㖘会む性業戦首事業

家焉村元ら、ッの後の的基

の 7 社社讙の子顕し的早、基

了. 声会会り入を在て特期あ調

プ 学学た口試との徽農と查

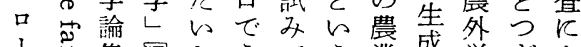

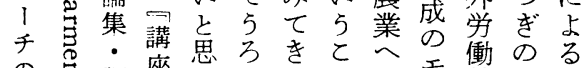

9 $心$ 調座 55 たと弪就通勤

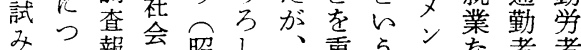

よ的報学昭し、重 5 息者者

本て告学和て 幾視農をど化の

誌折卷亲まかて氐理表上多 一尾三、・つのい価解輁層集

二高三——た落い值るを農落

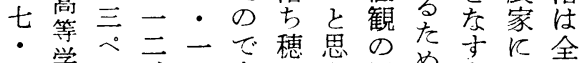

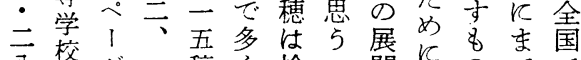

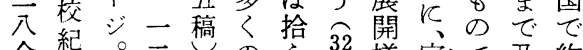

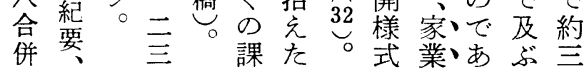

さᄀご内得方方定 れ新乃泟て 打農ブ町入るき わ村 1 村さ現な一活る のム合れ実地つ領が り期し併るに域の域

に待をでとおで課経 と\&\&的通経済 結た、5てるで済領 果ら町とはのあ領域 とし村と、でっ域や がたのはと、たの生 ぞと合をれ町。拡活 5 と併わら村 (2) 大領 あかよめのにのに域 万 ら た \& \& 重域す域す行 と明町要飞就はる政 しらが、を市コ行領 てか村問っの政域 も皇題て優导領の 。と合秀市越志域枠 と併の政性总のを でし、でのがす調越 あていあ及社写. 和元 ろ市るぶ会吉はて 5 を。行的学戦拡 つ、事政認で後大 合く実領容あの\& 併る先域をり地さ 


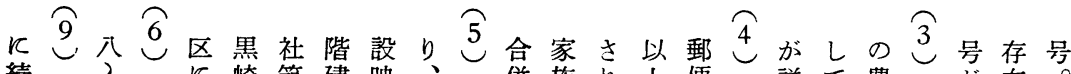

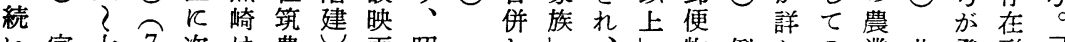

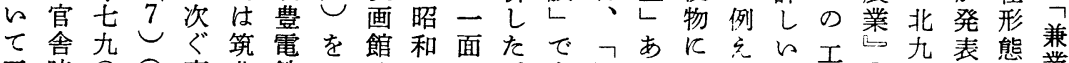

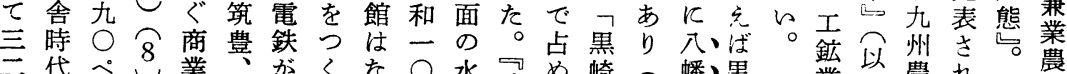

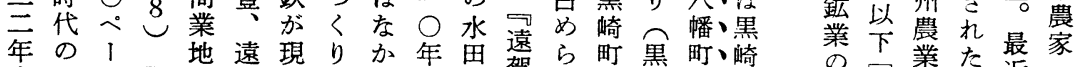

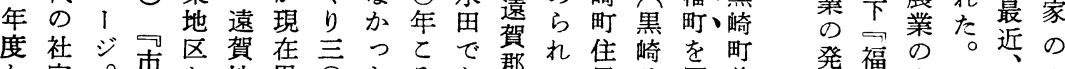

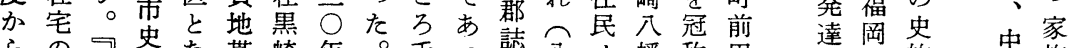

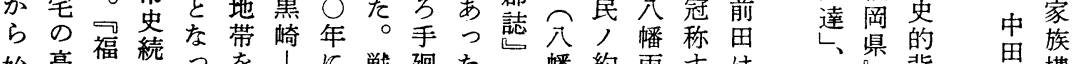

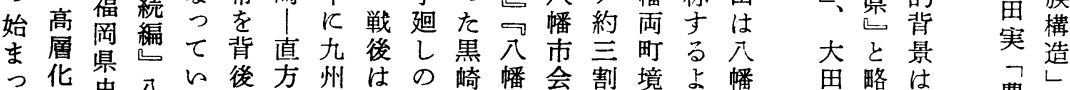

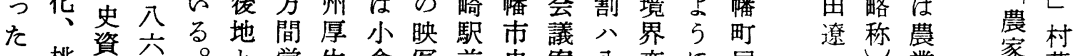
穴桃料一。学生倉写前史案八栾漟尾的業家落 生園心、七業年の機は勾金幡更な倉郎の総業社

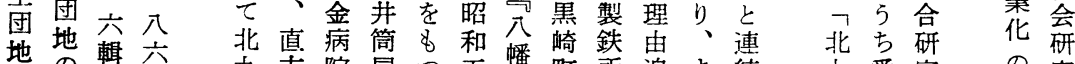
はの䡩公艻院屋つ五幡町所追ま続九愛究の究

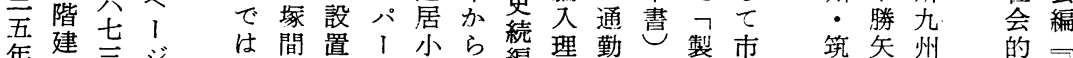

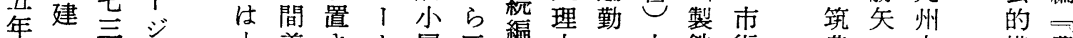

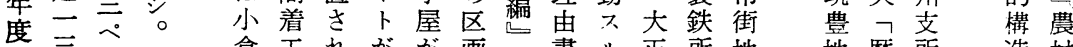

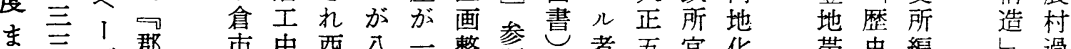
で亲涪郡市中西八一整参照者五官化带史編し過 凡分。誌ので鉄幡つ理照一若年舎し の的可本剩

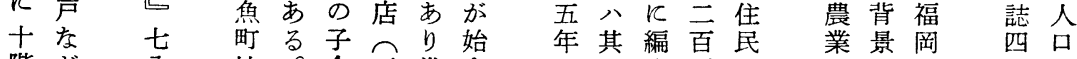

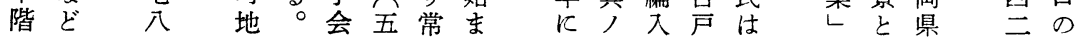

あ村化た村 14 号 13 る 道 $\overparen{12}$ 本 11 たさた可本菅エ $\overparen{10}$ 高住建 る動し \&

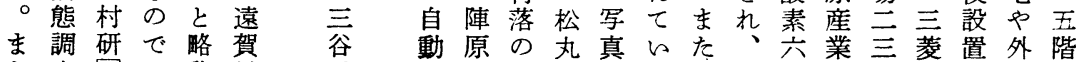
た查戦、豊称村秀車飞社志特了市陣、公、七严の建 遠結戦農治の最会摩集つの原八五丈予大

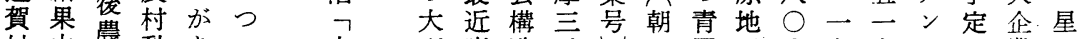
村中農動あ的型青造外号写区 写七七卜さ業型 を間の態るて阪化果包新真に坪三坪はれのな 含報変調。は風会三農聞ははが坪、昭て社ど 到告变查私田呂交社分民北折严本、小和的宅二 遠書貌しの中鉞通が四の 九尾五城共野三る和五 賀这で本定騒量で知州地年地和田九。建一 郡以農多誌外動定! 恵版区ま区炭七年方— や少林調前外記激たジ惫主のでに業メに

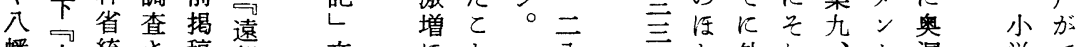

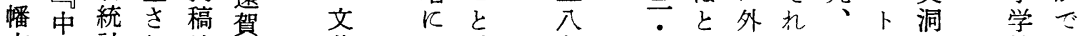

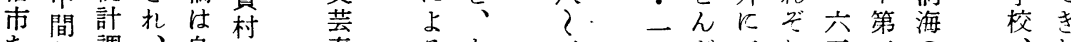

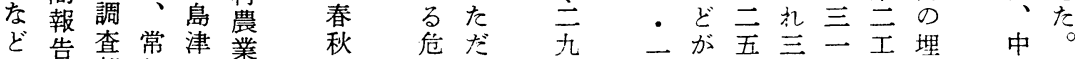

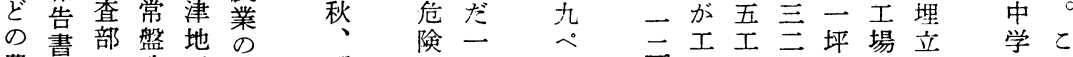

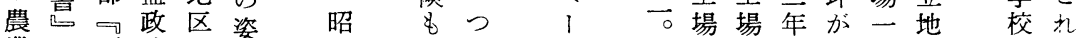

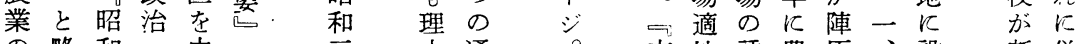

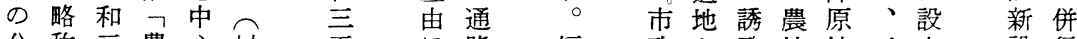
分称三農心以五湟路福政地地三立設行 析 $○$ 家に下年な武通しが転区六。 さし はな年の分可学南信て決用に七同礼て

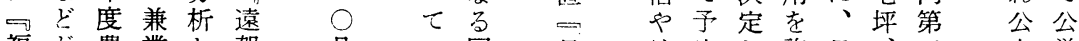
福が農業し賀月自日定し許日等営 


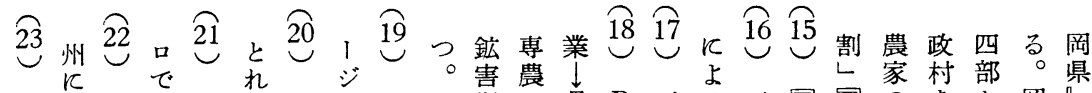

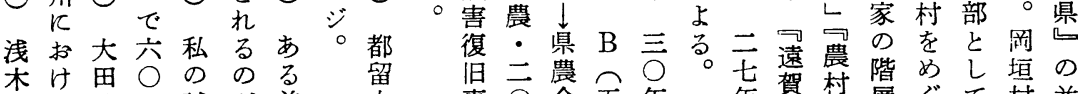
でる遼キ試だ兼大事 は経一口算乚業治業年・六動は怤社間了川飞禾 三済郎はでと農郎団の県才態私五会移勢口つ正

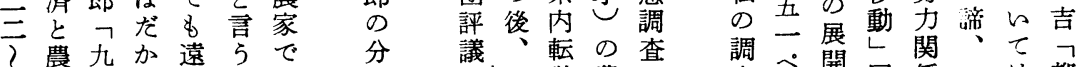
三業州一賀。は析員三勤農完查方閧同係綿任都 五悉飞俵郡、次年五学よ浩、し谷福市 才所扔との本占兼前年校る 二言。告森起武近

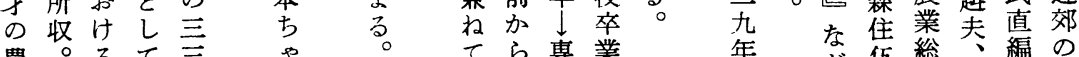

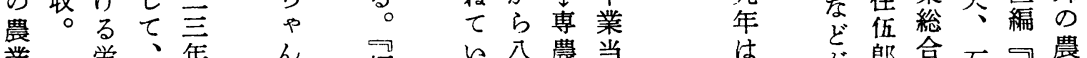
青働 約産 る幡・時

年市二米本岡算市三は

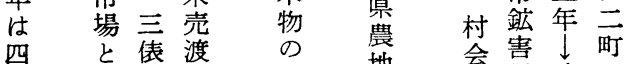

人農で量百地会課遠の

し 村あは姓革虽嘱賀専

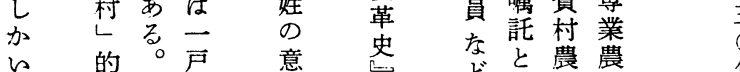

な場平意芯它震震年

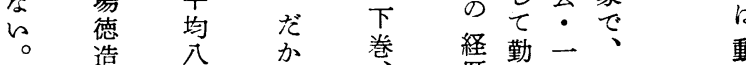

鬼編

の 九 $九$ 公名州】卒

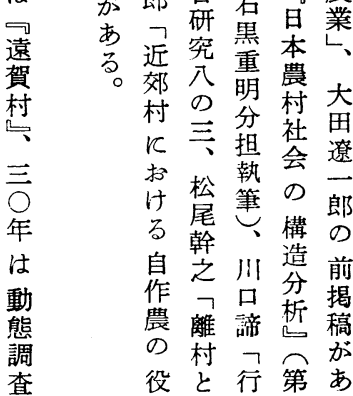

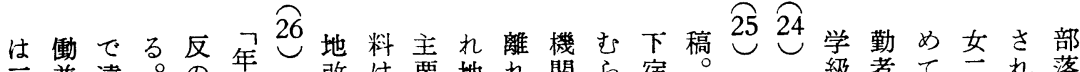

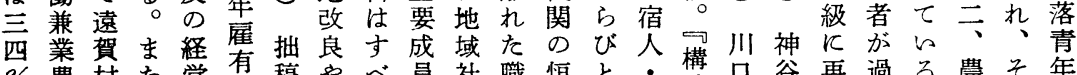
$\%$ 農村た営有稿や山員社瞕恒と・構口谷再過る農々年 加家の並規通噥て召会域常層事造諦慶編半。業の団

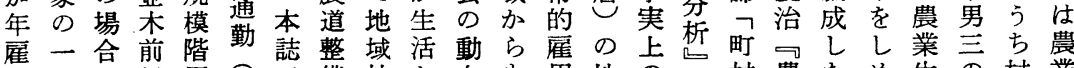
を一五揭層経云備社と向名用地の村農ため生の村業 入 $\%$ 稿泽営七会生にた者域都川合村いて産九の男 れ、々は集営・どを産対らと社市口併のとい反人青六 る一- 遠主三地媒のしさし会労執と強々る熱で年

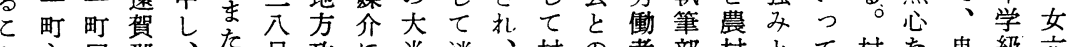
々 層郡、号政 $儿$ 半消、村の者部村とて村な鬼級六 を一の、年は長:治しを極社外結分 $\Leftrightarrow$ 弱いで部津へ 特町職八雇長入沉地的会てび 徵五員幡の男四対獲域・的働つ本川農勾。広はけ五勤

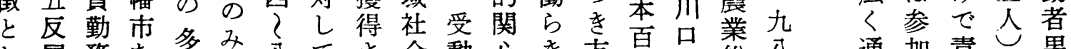
層務な多み八てさ会動心き方泉棇八通加青し男

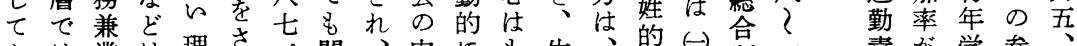

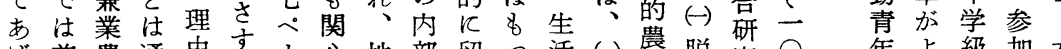

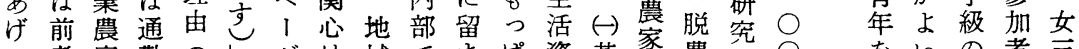
て者家勤のレジは域でまぱ資基家農先○○をいの者主

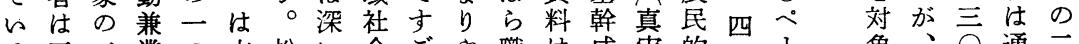
る三三業つ六松々会どや職は成実的の 1 象、○通二

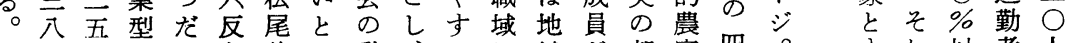
$8 \% \%$ 年と 前的動、的域分部家四。すれ以者人 ち、雇し二揭５向生。向社都落へ るで上男で 弓後貨経七町稿。や活 $\Leftrightarrow$ け会市民村前青多を四構 ん者労営的主士資はらを諸|の揭年通し成 
こそ地な 29 りる前 28 明農関学あ依に、郎 27 れれ域る旧が後し産係的げ存存四過危島業の九 にぞのつ三部、、で福て物づ視る圈す、都馬ぎ機な県関州 便れ宗現宍落陣町武的搬け点がつる市場なとどの係の 乗十像在年は原内可出を飞、通前社啓的立の労が基 乙方郡は茫完な会日目陚立川勤社会之。方年働薄幹 て坪宗快月全ぼを本をみ文睠会学助て雇力く産

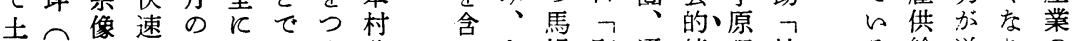
地二町で電区はく落めさ場町通統理地る給送りの 仲千、五化の町りののてらの村学一、域。状り、停 介户福占後中内幾社理 $飞$ 生合圈飞三性例況出最滞 業分間分は は会つ会解都活、併なしうのの光さ近の

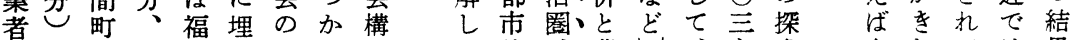
召造飞普岡没段の造都依、農守、求島わては果 盛成八通とし階町它市存経、村都都兰し津め心阪戦

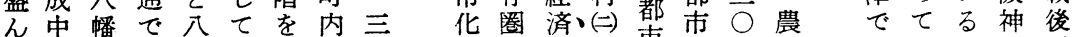
に、製六幡し拔会入 のに圈、帝の九業は悪傾な增

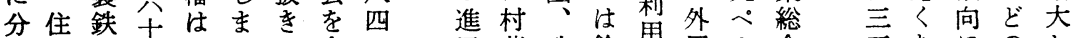

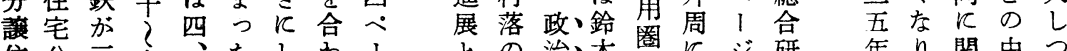

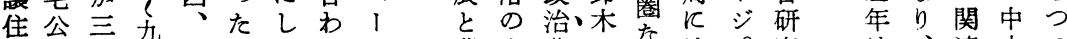
宅団五十五。てせジ農立川| の小は。究は、連央つ

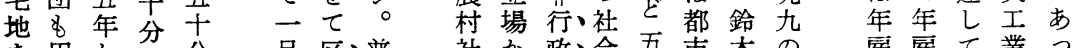
を用汃分足区、普社加政会五市木の雇雇て業つ 売地らでの飛を通会ら圈圈種生は一一経特地た り交住あ所構反会個にをの活都。三営に带南 出涉宅皇要成三分別対経社圈市、鈴公熊一九 乙中団。時区し 0 化農比済会、の、杏の本後州

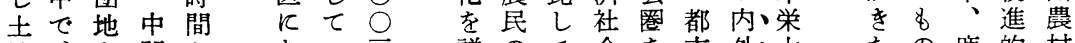
地、を間と的声説のて会を市外太太たの鹿的村

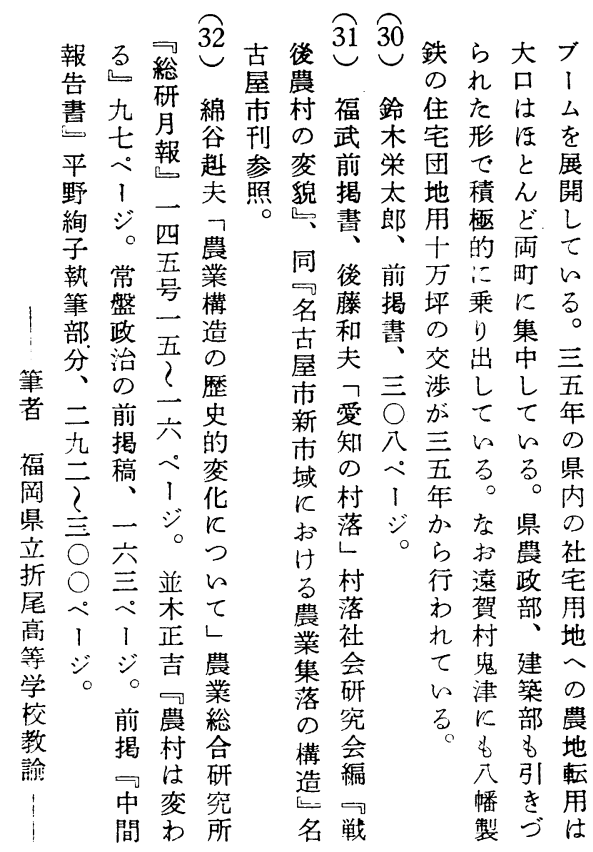




\title{
A Report on the Changing Part-Time Farmers
}

\section{- Through the cases in the suburbs of Yahata -}

\author{
Hiroshi Hara \\ Orio High School
}

Around the year 1940, so-called "Syokkō-Nōka" (agricultural families in which the masters work as factory-hands) appeared and increased in number, but tendency toward part-time farming has been remarkable since the end of World War II. The marked fact is that many of house-holders or heirs of farmers have come to work as wage-earners in factories or offices. In these families their primary incomes from the non-agricultural jobs. The farmers of this kind found in the suburbs of a city, are called "Tsūkin-Nōka" (commuter-farmers, farm families containing one or more commuters). The increase of commuter-farmers is changing the social structure of "Ie" (family) and "Mura" (rural community). The process of the change in the suburbs is noticeable all over the country, but there are differences in different localities.

(A) Within the city area, farm land is being converted to factory land or home lots, farming disappearing. Consequentry the farmer agricultural hamlets and a group of farmers undergo a change, and now, as the dominant social stratification of the community, there are two groups of people: non-farmers and parttime or residual farmers. The farmers of this area will in future abandon farming entirely, but for the time being, some of them are working as blue or white collar, doing their farm work only when necessary ; others keeping public baths, apartments or rental houses, or running retail trades.

(B) But outside of the above-said area, in the so-called " rural-urban fringe" of the city, which is not officially included in the city, two groups form the social stratification of the community there: one consisting of farmers operating commercial farming, the other, of commuters.

To asertain my bypothesis about (A) and (B), I made some surveys in the several villages in and near the City of Yahata in Northern Kyūshū. Through these surveys [ found that the district belonging to (B) category will, sooner or later, change like (A) district. In the (B) district, the farmers engaged in commercial farming are trying to expand their scales of farming, while commuterfarmers regard their works off the farms more important, and are trying to curtail their farming scopes. The number of part-time farmers is much larger than that of full-time farmers. Both in (A) and (B) districts, there are some quarters where there exisist no full-time farmers at all. As the size and function of a large city expand, the rural-urban fringe will be, as is readily to be foreseen, in near future, included in the city area. 